\title{
AIRPORT ENVIRONS - TASKS OF THE INTEGRATED DEVELOPMENT (USING THE EXAMPLE OF THE PULKOVO AIRPORT)
}

\author{
Michael Vilenskii', Ksenia Veretennikova² \\ 1,2 Saint Petersburg State University of Architecture and Civil Engineering \\ Vtoraja Krasnoarmejskaja ul. 4, St. Petersburg, Russia \\ vilenm@list.ru'
}

\begin{abstract}
This article touches upon the relevant issue connected with a world-wide tendency to the development of territories around airports. Development directions of the Pulkovo Airport and its adjacent territories in Saint Petersburg and the Leningrad Region are considered. Core activities concentrating in airport zones and factors conditioning their attraction to these zones are revealed. The notion of an airport environ is disclosed and introduced. The research defines the urban-planning and economic factors which allow carrying out the economic regulation in zones adjacent to airports and their influence on the spatial development of such territories.

The assessment of a change in the land value in the Pulkovo environ during its commercial development and the analysis of factors which form this value are given in the article. A number of problems of territories, which are under influence of the Pulkovo Airport, are revealed. Relying on results of the world experience analysis, authors note that the development of territories, located in the zone under influence of the Pulkovo Airport, shall take place in accordance with the single concept of the urban planning which does not depend on the administrative belonging of the territory and takes into account long-term strategic tasks and tools of the effective management.
\end{abstract}

\begin{abstract}
Keywords
Airport, Pulkovo, airport environs, aerotropolis, strategy, airport development zones.
\end{abstract}

\section{Introduction}

The contemporary state of the transformation of peripheral territories around the Pulkovo Airport within Saint Petersburg and the Leningrad Region denotes the necessity of the formation of the spatial development strategy capable to ensure the integration of the airport and the build-up territory formed around it with a new future site development and natural territories according to the stable model of the integrated development upon ensuring necessary public priorities.

The situation with the development of the territories around the airport leads to the fact that new forming zones of the extensive urban-planning development do not turn into a holistic and stable urban layout, but become discordant city fragments of the building-up in view of the insufficient attention to the role of the integrated development and integration of all territories around the airport with account for the natural framework maintenance.

The lack of understanding of the necessity of the formation of the single social and economic strategy of the territory development in the zone under influence of the Pulkovo Airport, as well as resulting absence of the single strategy of the spatial development and the united urban-planning documentation lead to the inevitable fragmentary mixed-function and mixed-scale building-up with the lack of internal connections between individual territories, availability of conflict zones connected with mutual limitations, with ousting of natural components and appearance of blank spaces within zones of limitations related to the activity of the airport.

Modern theoretical models of the spatial development of zones around airports and the practice of their application can become the basis for revealing alternative approaches in the solution of many of the above problems in the spatial development of peripheral territories around the Pulkovo Airport within Saint Petersburg and the Leningrad Region.

Considering examples of the spatial development of territories in zones of airports of cities of the world, we can see to what extent the involvement andintegratedness of 
these territories in the urban agglomeration structure and intra-urban web changes the quality of the environment towards interests of the city and the man, allows using resources and features of such type of territories effectively. The main objective of this research is the determination of the development direction of the territories in the zone of the Pulkovo Airport in Saint Petersburg and the Leningrad Region. The Pulkovo Airport has the international status and is the only regular civil airport in Saint Petersburg and the agglomeration of Saint Petersburg. Issues concerning the transformation of the territory around the Pulkovo Airport are extremely sharp today, since the active development of these territories, which faced a number of problems being unsolved till now and which partly provoked them, has been carried out for the last fifteen years.

Following the value of the territories being transformed and planned for the transformation around the airport at the present time, there is a chance to change the situation in the city. Vast areas which are not well-developed yet could become binding zones and constitute parts of the extremely needed infrastructure, including transport and green infrastructures, ensuring sustainable development of the territories in the airport zone.

\section{Subject, tasks and methods of the study}

The modern stage of the transport infrastructure evolution began in the middle of the 19th century and continued in the 20th century passing active stages with the development of different types of the transportation. In the 21st century airports have become one of the key facilities of the transportation infrastructure, since they represent a type of transport that most effectively meets the requirements related to the population mobility. At the present time, airports cease to be exclusively infrastructure facilities, "becoming an integral part of the urban landscape" (Donnet, Keast, 2010), transform into more complicated spatial complexes. They evolved from "autonomous facilities on the periphery of cities" (Thierstein, Alain, 2010) into intermodal transfer hubs having potential to the concentration of economic, investment, and urban-planning activities. "At the present time, airports undergo the considerable development in the field of business, besides their primary aviation services, they develop a significant number of non-aviation services and gain a considerable part of income from the non-aviation production" (Kasarda, 2012). The gradual commercialization of the airport is explained by the influence of processes of globalization and liberalization (appearance of lowcosters, appearance of "hub and spoke" networks, creation of global alliances of airlines), and airports were to diversify income sources which gave an impetus to the development of business and the service sector in close proximity to the airport (Marcos, 2015).

There is only one regular civil Pulkovo Airport in Saint Petersburg, wherein the construction of a new terminal in 2013 was completed (http://www.pulkovoairport.ru/about/ history). According to the data of the "Northern Capital Gateway" operator company of the Pulkovo Airport, the passenger traffic amounted to 13.4 million passengers in 2015; an increase in the passenger traffic up to 22 million passengers per year is planned by 2025 .

For cities, similar to Saint Petersburg having on its periphery a large airport with the lack of the single development strategy for the zone around the airport, as well as a very low level of the urban-planning development, connectivity of the territory in this zone and the environmentally problematic situation, the necessity of the search of an optimal model of the transformation of territories in the airport zone is quite obvious. The effectiveness of the use of the territories in the zone around the airport within the framework of the search of a compromise between interests of developers and interests of the urban community becomes particularly important for Saint Petersburg.

The subject of this study is processes of the transformation of the territories around the Pulkovo Airport. The object of the study is the territory around airports. There is a number of zones in the Russian legislation which are allocated around airports. For example, the concept "aerodrome environs" (introduced by the Federal regulations of the use of the air space of the Russian Federation approved by Decree of the Government of the Russian Federation No. 138 as of March 11, 2010 ) is an area of the land or the water surface adjacent to an aerodrome within which (for purposes of ensuring safety of flights and avoidance of an adverse effect on the human health and the activity of organizations) a zone with special conditions of the territory use is established. There are notions of an approach funnel zone, a sanitary protection zone of the airport, a roadside clear zone of the airport, a zone of the housing construction ban and some other zones. However, all these zones are only zones of restrictions from the airport and they do not define such territory, within boundaries of which its influence on economic processes and, correspondingly, on the spatial and functional development is carried out. At the same time, such territory is formed around all large airport terminals. Its feature can be both the special legal regulation order focused on the development of such zone, and autogenous processes and various possible combinations. For example, in the USA and a number of other countries, such regulation zone is defined as an Airport Development Zone.

Airport development zones (ADZ) are special tax areas which grant privileges to taxpayers for economic projects in the special allocated airport zone. In fact, this is something like special economic zones in the Russian Federation. There are similar definitions for such allocated zones in many countries. However, in case when we bespeak territories, whereon economic development processes are connected with the airport activity, but development can be carried out both with allocation of special economic zones and without specially regulated tax or other conditions - the introduction of an individual notion is necessary. Within the context of this study, the notion of an "airport environ", which can be defined as "a territory around the airport connected with it not only by adjacent location but being under its economic, transport 
and "image" influence", is applied (Veretennikova, 2016). This definition considerably extends boundaries of the zone - ADZ and allows proceeding subsequently to the definition of urban-planning characteristics of this territory at its establishment.

The research tasks are the determination of factors and conditions influencing the transformation of the airport environs and, correspondingly, the formation of boundaries of such territories and the use of urban-planning and legal tools of their regulation. Various methods of a system spatial analysis of the territory, a land bank assessment method, a number of other methods are applied. In order to analyze a range of problems and determine ways of the transformation of the airport environs, the authors used materials of the implemented and completed works including those executed with their direct participation, as well as developed conceptual proposals for the territory development in the Pulkovo Airport zone executed in the course of the last ten years.

The most essential urban-planning factor allowing carrying out regulation in the similar zone is the factor of the establishment of a spatial boundary of such territory. However, its boundaries can change substantially with due account for the time, paces of the territory development and its regulation regimes. What determines boundaries of such territory? Key factors are the economic attractiveness of the territory, technical restrictions of the airport and the balanced stability of the spatial development with due account for the natural framework of the territory.

Let us consider how these factors of the development of the territories influence on the spatial development of the airport environs and to what extent this condition is applicable to Saint Petersburg.

Let us turn to the study executed by urbanists of the Dutch-Swiss company Güller Güller, headed by Mathis Güller and Michael Güller, in 2001, who proposed three categories of the economic activity by features of its connectivity with the airport:

- Aviation types of activity being a part of the maintenance of the airport.

- Activity connected directly with freight and passenger traffic flows (logistics, retail trade, hotels).

- Activity selecting an airport zone in view of its image, relative low land prices and good provision with an infrastructure (Güller, 2001).

If first two types of activity have already become rather habitual and inseparable from the airport, the recognition of the existence of the third one and understanding of the necessity of its regulation is lacking in Russia at the present time.

What types of activity are formed in airport zones and what attracts them? The carried out analysis of the airport environs of Europe, the USA, Russia and China shows that such territory has a high degree of the functional variety. It can include logistics parks and distribution centers, business and technological parks, industrial facilities, health care institutions, campuses, hotels and entertainment centers. Airports become "centers of the informa- tion, knowledge and competencies exchange" (Kasarda, 2012), which results in the allocation of science intensive companies of various profile near them. Large housing estates can also be situated within the airport environs, out of noise nuisance zones, and this is by far not the complete list of functions in such zones. Significant territories continue to occupy agriculture facilities taking into account vast zones of restrictions of the capital construction.

Why are the zones adjacent to airports so attractive in comparison with other territories? What makes them more economically attractive in comparison with many other territories?

It is the territory "image" (http://www.slideshare.net/ IAUIDF/key-factors-of-attractiveness-for-airport-areasand-the-special-role-of-human-resources). It is achieved through connection with a recognizable facility - the airport, where potential customers from all countries and regions of all levels arrive: from ordinary consumers to the economic and political establishment; through connection with modern high technologies with which the airport is associated; through high standards of the service and design, to which modern airports tend; through ultramodern architecture of complexes of airports; through the effective vicinity to those facilities which have been already allocated in such zone.

These are land prices. Airport zones remained unclaimed for the development for a long time due to the building-up restrictions. However, in the last 20 years, the modernization of the aviation park gradually reduced boundaries of restriction zones according to a number of indicators, and by a certain stage zones around airports turned out to be a considerable free land reserve situated relatively not far from the city. These territories were partially built up with various facilities of municipal and logistic purpose owners of which were ready to sell them or convert them for a different function taking into account the increased demand. Thus, the land value in the zones adjacent to airports was and partially remains low due to volumes of the free land bank.

It is the infrastructure of the airport environs which has significantly higher level of the development in comparison with any other new territories, and at the same time a considerably bigger potential in comparison with zones which have already formed. First of all, it concerns the transport infrastructure. The network of highways, including high-speed ones, makes such territories extremely attractive for the development of various functions both connected with freight traffic and with the transfer of the significant amount of people. The engineering development of the territory also influences the attractiveness of airport zones; however, this factor can be not developed enough since systems of available power of airports are often absolutely self-sufficient and cannot provide additional resources for the stimulation of environment.

A number of important urban-planning problems, to which insufficient attention is paid in Saint Petersburg, noted in studies of specialists, include ignorance of capabilities of the natural framework in the urban development 
(Nefedov, 2017). The situation, wherein the natural framework is not considered as the important functional and compositional part of the new urban landscape, becomes the result of a rapid growth of peripheral territories at the boundary of Saint Petersburg. It relates to all peripheral territories in Saint Petersburg. It is particularly relevant for the airport environs, i.e. those which are in the zone under influence of the airport situated on the periphery of Saint Petersburg, taking into account its "transboundariness" - location both in Saint Petersburg and the Leningrad Region. This territory is not taken into account in the system of the urban landscape in both territorial entities and it has been subjected to the most massive influence for the last period. At the same time, the territory has the enormous potential for the maintenance and development of the natural-landscape framework taking into account the conservation of large free and not built-up territories with woodlands, water bodies and natural landscape.

It is necessary to emphasize among the most noticeable problematic qualities the excessive building-up density of new multi-functional quarters in the total absence of internal ties both between them and between them and the airport. Forming chaotically arising built-up territories, including those in the form of individual large consolidated mono-functional zones, the urbanized environment excludes appearance of green corridors and leads to the formation of separate spontaneous temporary green "oases" in the zones, wherein according to technological characteristics of the airport, building-up is prohibited. The conflict situation to which this quality leads lies in the lack of the possibility to form a branched natural framework between individual territories and built-up quarters, destruction of separate formed natural biotopes and in the lack of the possibility to maintain natural green zones in the structure of separate territories. Such environment not only disrupts the ecological balance, but also forms alienation of the population from green spaces, losing zones of the potential rest of people.

At the same time, the zones around airports often have a high green potential throughout the entire world, and such potential contributes to their attractiveness and resistance to changes. For example, according to the opinion of J. Kasarda, the transformation of green zones around airports in China with the conservation of their natural and recreational nature is a priority. According to his opinion, the Chinese, when implementing their programs of the development of airports and zones around them, consider airports as "competitive assets" rather than "troubles and environmental threats", and many municipalities insist that they, i.e. the zones around airports, shall turn into green "environmental cities" (http://www.economist.com/news/china/21646245-chinas-frenzied-building-airports-includes-work-city-sized-projects-aerotropolitan-ambitions).

How do all these and other factors influence on the spatial development of the airport environs and what is

Table 1. Concepts of the development of the airport environs

\begin{tabular}{|c|c|c|c|c|}
\hline \multirow{3}{*}{$\begin{array}{l}\text { Name of the } \\
\text { concept }\end{array}$} & Author & Year & Description & Features \\
\hline & Roeseler & 1971 & & \\
\hline & $\begin{array}{l}\text { Freestone and } \\
\text { Baker }\end{array}$ & 2011 & & \\
\hline Airport city & H. McKinley Conway & 1980 & $\begin{array}{l}\text { More or less dense accumulation of } \\
\text { enterprises connected with the airport on } \\
\text { the territory of the airport and around it }\end{array}$ & $\begin{array}{l}\text { A large volume of various service functions: trade, hotels, } \\
\text { entertainment } \\
\text { Focus on business } \\
\text { Has qualitative characteristics inherent in the city: density, services, } \\
\text { access quality }\end{array}$ \\
\hline Aerotropolis & J. D. Kasarda & 1991 & $\begin{array}{l}\text { Agglomeration around the airport (http:// } \\
\text { www.aerotropolis.com/) }\end{array}$ & $\begin{array}{l}\text { Replication of services of the airport city } \\
\text { Characterized by radial transport connections } \\
\text { Similarity to "the airport corridor" concept } \\
\text { "Dominating city" (Kasarda, 2012) }\end{array}$ \\
\hline Airport corridor & Marije Schaafsma & 2008 & $\begin{array}{l}\text { The airport corridor arises in the area } \\
\text { which connects the airport with the city } \\
\text { center }\end{array}$ & $\begin{array}{l}\text { Situated between the airport and the city } \\
\text { Contributes to the stable integration of the airport into the city } \\
\text { structure } \\
\text { Connected to the city and the region by highways and railway } \\
\text { "Can become an obstacle for the chord urban development and } \\
\text { lead to the growth of the fragmented line building-up" (Schlaack, } \\
\text { 2010) }\end{array}$ \\
\hline Airea & $\begin{array}{l}\text { Johanna } \\
\text { Schlaack }\end{array}$ & 2010 & $\begin{array}{l}\text { "The matrix of the fragmented } \\
\text { building-up islands connected with } \\
\text { the airport" (Schlaack, 2010) }\end{array}$ & $\begin{array}{l}\text { Building-up fragments can be situated at a large distance from the } \\
\text { airport } \\
\text { Has similar features with the concepts of "airport corridor" and } \\
\text { "aerotropolis" }\end{array}$ \\
\hline
\end{tabular}



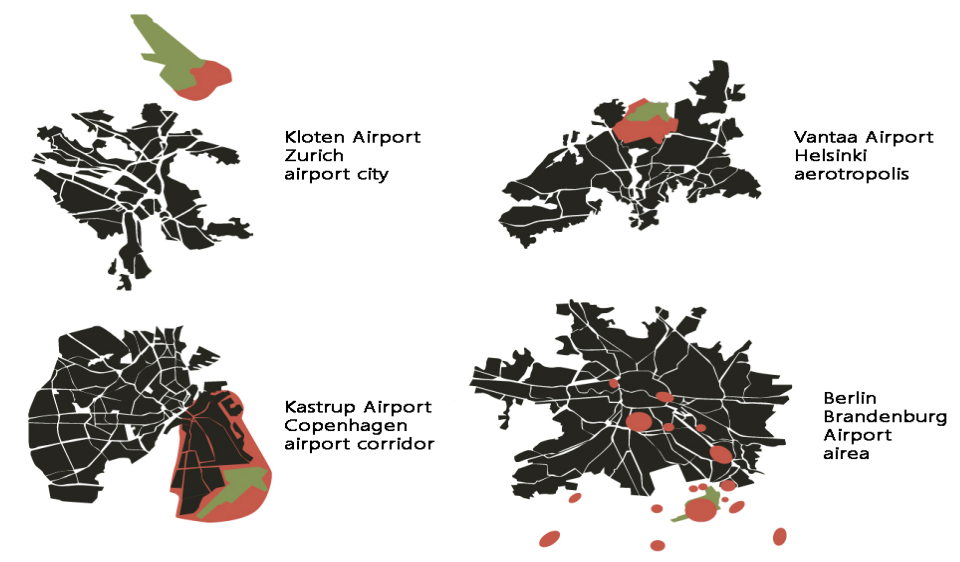

Figure 1. Examples of the formation of different models of the airport environs with the overlap on spatial urban patters

the connection of the city and the urban agglomeration with the airport? In different conditions, factors, which we considered above, begin to form the new urbanized territory in different ways. Availability of different prerequisites in the form of the development of some conditions or the shortage of others, as well as features of directions of the economic development of a city or an agglomeration, characteristics of the airport itself influence on the planning development as a whole. At the same time, the normative and economic controllability and adjustability of the development of the zones adjacent to airports in the presence of the common concept of the development of the city territory or the urban agglomeration in combination with the airport zone development or an individual concept of the airport environs is the essential difference of the formation of certain forms.

The spatial development of the airport environs can take various forms that follow from concepts of the development of the territories around airports, existing in the international practices (Table 1):

- Dense building-up on the territory or in close proximity to the airport which has qualitative characteristics of the city (airport city).

- Corridor building-up extended along the infrastructure connection between the city and the airport (airport corridor).

- City with the airport as the building-up core (aerotropolis).

- Building-up connected with the airport having the disperse nature (airea).

Further in the article (Figure 1), diagrams reflecting the practical formation of different models of the airport environs with overlap on the city spatial development are given. In particular, the cases when concepts turned out to be implemented most neatly and without distortions or are in the final phase of the formation are provided: airport city - within Kloten Airport in Zurich; aerotropolis - Vantaa Airport in Helsinki; airport corridor - Kastrup Airport in Copenhagen; airea - Willy Brandt Berlin Brandenburg Airport.

The research on the analysis of the formation and the development of the airport environs throughout the entire world conducted by the authors within the study of the development of the Pulkovo Airport shows that theoretical models proposed by different researchers and analyzed by the authors are not alternative or mutually exclusive formats of the development of the airport environs, but reflect various approaches to the solution of problems connected with the development of such territories. Upon comparison of the proposed theoretical models, it has been revealed that the principle of the integral urban layout is the cornerstone of all of them, i.e. all of them propose the formation of the united zone - with its connections with the airport, with the city and with subzones within such zone. This principle is not conflicting even in case with the distributed airea model. There are differences in the density organization of the zone adjacent to the airport and the priority of prospects of its development for a certain time interval connected with the development of the airport and the city. As a result, it is seen in terms of a considerable number of examples that it is extremely difficult to emphasize pure models implemented within transformations of the zones adjacent to airports. For example, in case with the Pulkovo Airport we can observe signs of three concepts at once: airport city, airport corridor and aerotropolis.

In Saint Petersburg, against the background of the active development of the territory around the airport, there is a problem in the lack of the worked-out strategy of the development of the airport environs and the concept of the air transport for the urban agglomeration as a whole influencing it. Moreover, the similar concept shall cover the issue of revealing the necessity of the appearance of new airports or the expansion of the existing airports and their influence on the urban agglomeration. The problem of the airport environs exists both for Pulkovo and a probable new airport which can appear within the boundaries of the Saint Petersburg agglomeration in the nearest 1015 years. In order to reveal a current state of the problem, it is necessary to turn to the evolution of the territory development.

The evolution of the development of the airport environs in the Pulkovo Airport zone began in 1932 when "Shosseynaya" Aerodrome named by the adjoining rail- 
way platform was put into operation. The residential district "Aviagorodok" including several dwelling houses, a school, a shop and a first-aid post was raised together with the aerodrome construction. These are the first non-aviation functions which appeared in the airport environs. In 1951, a new building of "Shosseynaya" air terminal was opened according to the project of architect A. Gegello. Opening of the new airport terminal according to the project of A. Zhuk took place in 1973. The airport got the name of Pulkovo. Since the late 1990s, the gradual concentration of the activity around the airport has become more and more obvious. In 1986, a renovated air-terminal complex Pulkovo-2 was opened (http://www. pulkovoairport.ru/about/history).

For the Pulkovo territory, as well as for other Russian airports, the stage of the formation of the market land value in this zone and the privatization period prior to it, which began in 1991, became one of the key stages of the evolution of the development of the territories around them. Lands around the airport began to be actively developed. In 2013, the construction of a new Pulkovo terminal was completed.

The land value in the airport zone is formed taking into account the possibility of its use and reflects the market demand for certain facilities with due account for the competition and the market capacity, legal urban-planning regimes of the land use and airport restrictions including burdens imposed by radio navigation systems, height restrictions, safety requirements, environmental state of the land and the air basin, the current state and the planned development of the transport and engineering infrastructure. Additional restrictions could be imposed by the facilities functioning in the airport zone including such facility as the Pulkovo Observatory. Another significant factor is the development of the airport itself taking into account its capacity, the number of airlines and plans for the further transformation. Another considerable factor is the development of different functions, first of all, residential and production functions in the frontier zone which is actually not connected with the airport directly through functional connections, but influences the attractiveness of the arrangement of certain facilities in the airport zone.

What of these factors and how influenced the development processes at the Pulkovo Airport environs? It is possible to retrace the attractiveness of certain territories for investments with due account for their development and the market land value change.

The lands around the Pulkovo Airport before the privatization stage in 1991 were used, first of all, as agricultural and belonged to a number of large agricultural enterprises. As a result of the privatization, actually more than 4,000 ha were privatized and turned out to be involved in the turnover. Most of them ceased to be used as agricultural lands taking into account low economic effectiveness of this activity in the specified zone and the enhanced pollution of soil and the air basin in the airport zone.

The market land value in the Pulkovo Airport zone increased sharply in the range from $50 \%$ up to $250 \%$ during the last ten years (according to the data of ARIN LLC). Not more than $40 \%$ of the territory (according to the data of the authors, obtained in the course of works on updating (site plan Territories of the zone under influence of the Pulkovo Airport, as well as a number of other works executed by the order of the Investments and Strategic Projects Committee of Saint Petersburg during 2009-2012)) were in the ownership of the city and municipal authorities of the city and the region in the zone restricted by main roads adjacent to the airport by 2010 .

A particular interest among developers in the last 8 years was drawn to lots whereon the construction of apartment buildings was allowed but in view of the underdevelopment of the transport and engineering infrastructure and the lack of the program of the full-scale environmental recovery of the territory, a considerable part of projects was not implemented. The attempt of the residential building-up in the technical zones of the airport resulted in the cancellation of a part of projects, and another part of projects had a considerable negative effect on the Pulkovo Observatory complex situated in the airport zone.

The active formation of the business zone in close proximity to the airport was restrained in many respects by the lack of large companies of tenants, on which similar facilities are focused. However, coming of companies related to PJSC Gazprom and opening of the largest exhibition site "Expoforum" resulted in a high degree of occupancy of office facilities and increase in the further demand for office areas in this district.

With the increase in the airport capacity and the development of business and exhibition functions around it, the development of hotel facilities became needed too. The development of trade functions was in many respects influenced by the active development of the residential development in the southern part of the city and the transport infrastructure development - the Saint Petersburg Ring Road and the Western High-Speed Diameter. At the same time, it is possible to retrace a gradual change of the attitude to the formation of shopping facilities in this zone. The commercial development around the Pulkovo Airport began mainly in 2006, when a large number of hypermarkets appears on the Pulkovo Highway; the drop in demand in the crisis period resulted in the low occupancy and attendance of trade and entertaining facilities, and, therefore, in the appearance of the term "cemetery of shopping centers" in 2008 ("Institute of Business Activity Problems" LLC, A. Shaskolskiy). However, the general development of the territory changed the market situation and made shopping facilities more attractive, which can be retraced at next stages of the territory development when five more large shopping facilities appeared in the airport zone.

The service and technological domain has actively developed in the last five years too. Representative offices of companies with their own sites selling equipment (transport and construction equipment) appear in the airport zone. At the same time, there is the development of forming industrial sites along Volkhonskoye Highway and Gorelovo, as well as in the adjoining part of Shushary. At 
the same time, the tendency towards the development of the peripheral territories adjacent to traffic arteries in the airport zone with the developed engineering infrastructure is observed. Other territories actually remain free. At the same time, it should be noted that practically all sites at certain time were or are available for active sale. The size of the sites being sold varies from 20 to 250 ha. Their considerable part is still on the market at the value of $\$$ 30-120 per meter. The value in many respects depends on characteristics of the territory, however, taking into account sizes of plots, in general, they are diverse in respect of restrictions and urban-planning statuses. As a result, there is a considerable land bank of territories for the future development in the airport zone today, which is not involved in the development at the present time and does not include green zones. Actually, it is the territory having the area of 2,500 ha. A great part of these territories is not covered by the documentation on the territory planning approved or being developed at present. As we see, builtup territories are formed by separate locations which are not connected with each other and have no connections with the recreation.

Thus, in the Pulkovo Airport zone, prerequisites for the development of the territory within three concepts at once have been formed by now: the airport city in the form of the large scope of different service functions and the high density of the development in the zones connected with the arrangement of airport terminals; the airport corridor with regard to the active development of the territories along the highways connecting the airport and the city (first of all, it is the development along the Pulkovo Highway); the aerotropolis as the replication of services of the airport city around the expanded airport zone along the main radial highways (Figure 2).

How was the attitude of the city and the region to the development of the territories around the airport in the last 15 years formed? It shall be noted that in Saint Petersburg and the Leningrad Region the tendency to the integrated development of the entire territory in the airport zone both for two territorial entities and within one territorial entity could not be retraced for a rather long time. The work package on the preparation for the development of urban territories in 2009 by the initiative of ISPC (Investments and Strategic Projects Committee) can be noted out of city initiatives of Saint Petersburg. As for the rest, city initiatives were limited to the development of the external transport infrastructure and the airport zone itself directly. The integrated development of the airport environs was provided neither jointly nor independently as a part of documents of the spatial planning of the city and the region. There was no and there is no even a separate type of functional and territorial zones with due account to the situation in the airport zone. As a result, solutions in all documents were limited to the allocation of separated functional zones without a single common development concept. The development of the documentation on the territory planning also did not take into account the integrated development or special function of territories, which can be seen by the nature of the allocation of territories (Figure 3). In particular, no united traffic scheme or formed natural and environmental framework of the territory were provided; boundaries of

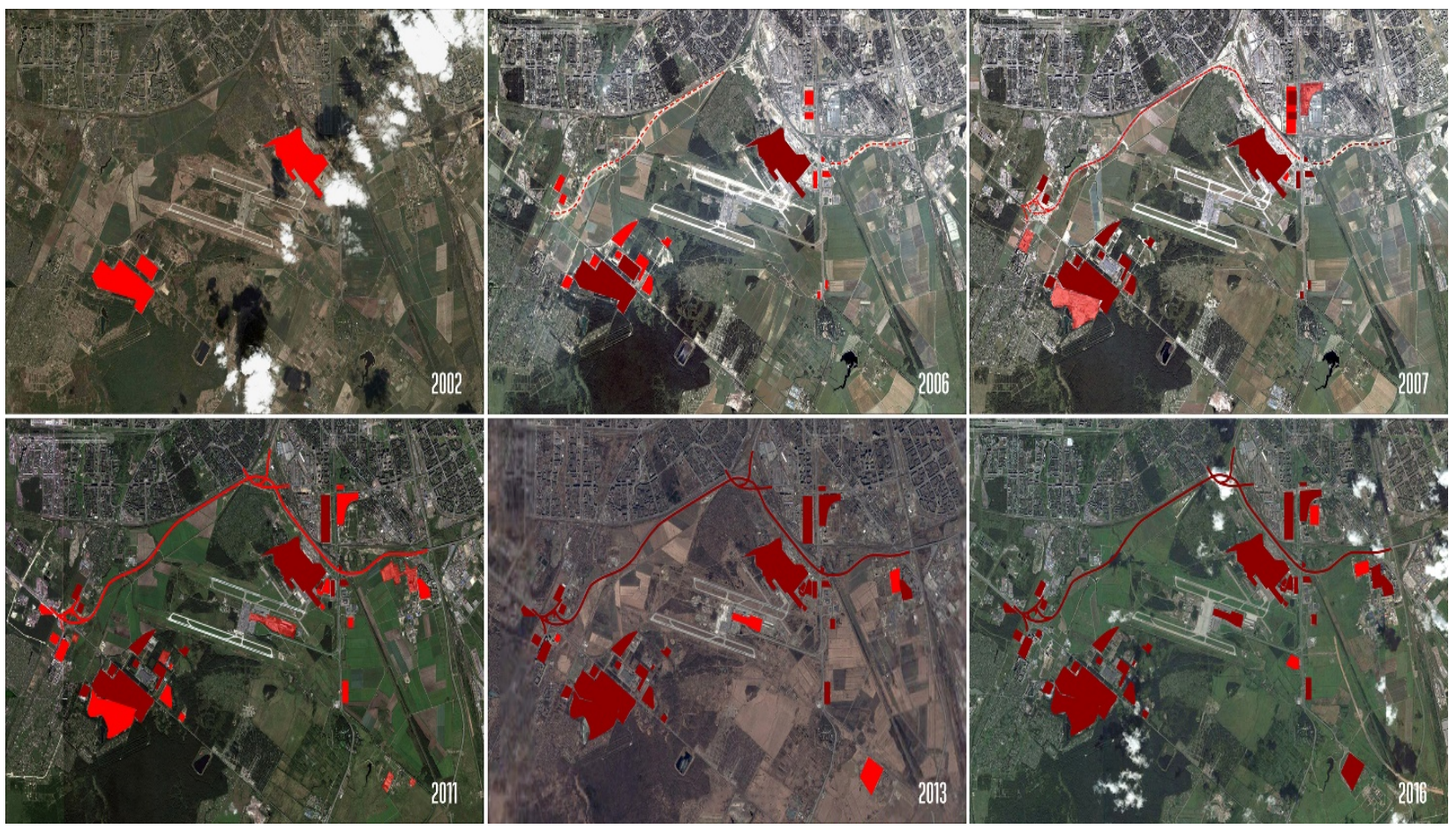

Figure 2. Dynamics of the development of the Pulkovo airport environs (based on Google maps) 


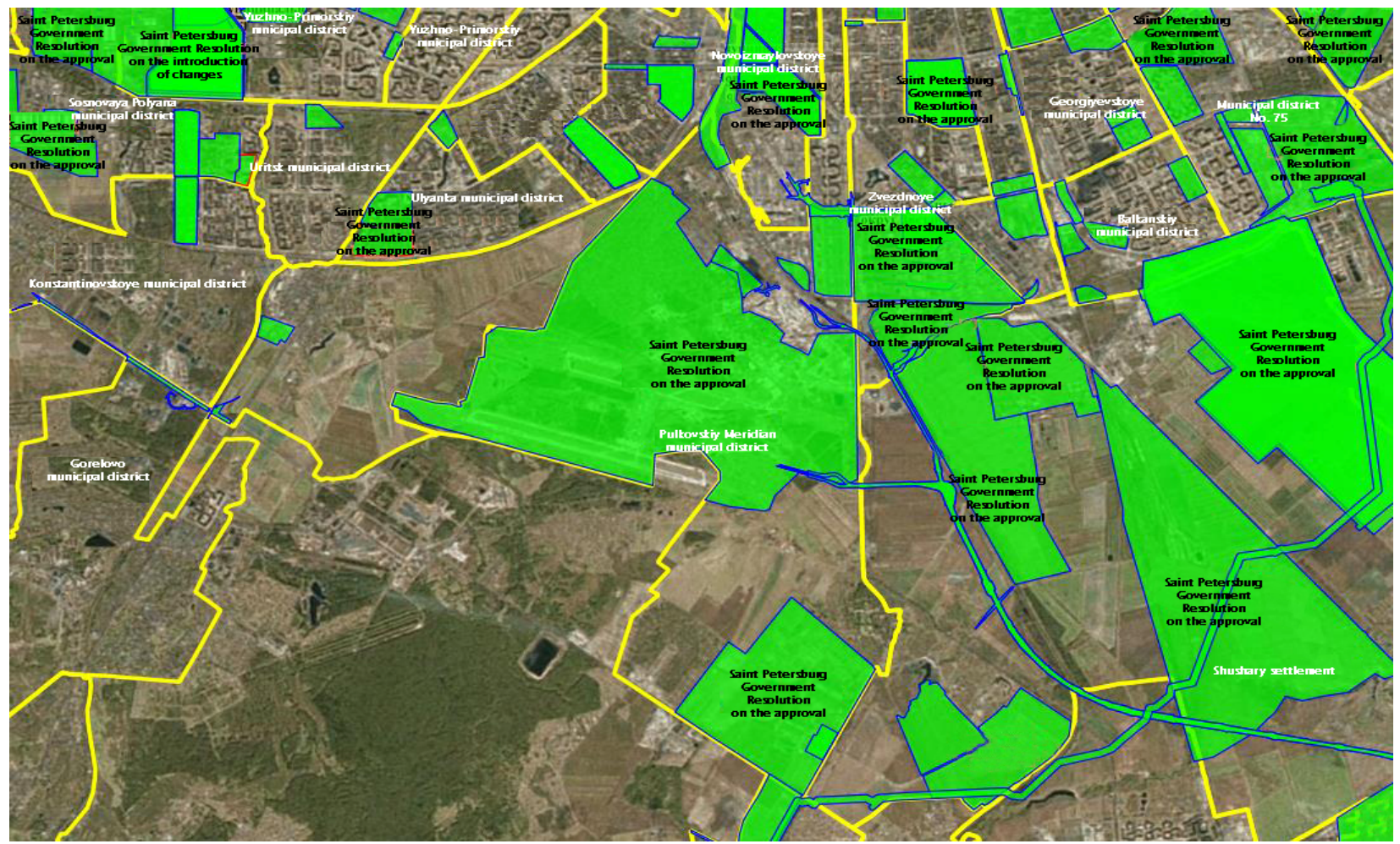

Figure 3. Approved planning designs in the zone of the Pulkovo Airport environs (Saint Petersburg)

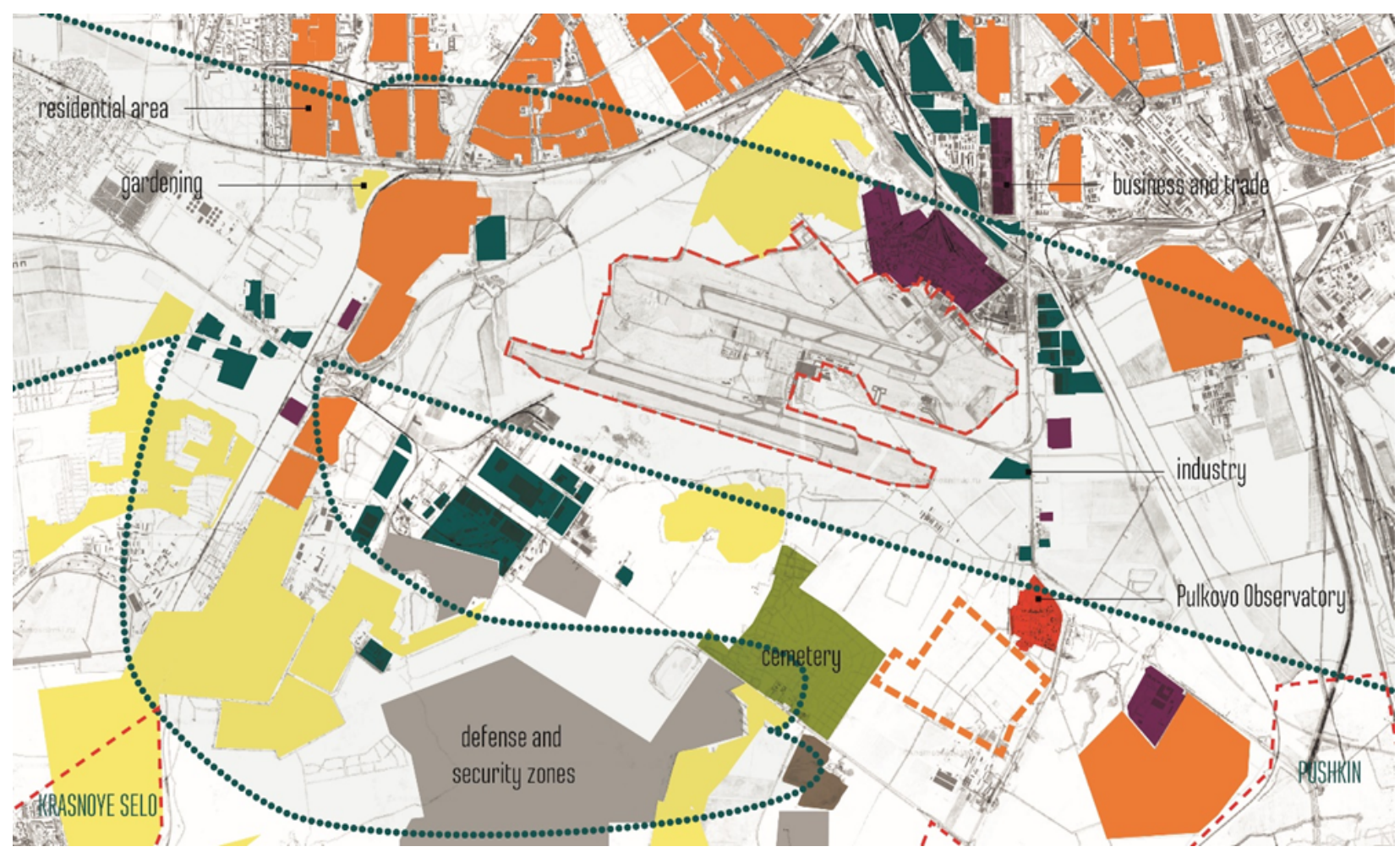

Figure 4. Existing functionality of the Pulkovo Airport environs 
the allocated territories are not bound to the general spatial and planning development.

The results of the current state of the territories in the airport zone are presented on the following diagram (Figure 4). The shift of the urban-planning activity in Saint Petersburg towards the southern outskirts of the city has been observed in the last five years. The importance of the factor of proximity to the airport shows the increase in a number of large-scale developer projects; a number of large-scale housing projects including such projects as the satellite town of Yuzhniy are actively formed. Moskovskiy District becomes "the second district of the business activity in the Saint Petersburg agglomeration after the historical center" (Goncharova, Romanyuk, 2013). All transformations become prerequisites to the necessity of the integrated development of the airport environs in the Pulkovo Airport zone.

To determine the development direction of the Pulkovo Airport in Saint Petersburg, a number of problems at the territories, which are under its influence, have been revealed:

- imbalance of the forming building-up, its negative influence on the airport, natural environment and influence of separate facilities on each other;

- formation of the individual territorial enclaves which are not connected with the general urban-planning structure;

- lack of the developed transport infrastructure in the airport zone;

- "lack of the convenient and fast transport connection of the Pulkovo Airport with the central communication district of Saint Petersburg" (Laboratory of urban planning, 2015);

- incompleteness of the integrated transport system.

- inefficient use of the territory resource, undeveloped economic potential;

- high percentage of closed territories;

- lack of the integrated single concept of the development of the airport environs;

- unconformity of the urban-planning documentation.

\section{Results}

Considering the above-mentioned, the development of the territories around the airport of one of the largest cities is a naturally determined process which gains the spontaneous nature without any single development strategy. It results in the appearance of separate building-up clusters which are not connected with each other and with the surrounding territory. It should be noted that we mainly bespeak international airports in the largest cities having or striving for the "hub" status. Such scenario of the development as "coexistence" when "tasks of the territorial planning will remain focused on the decrease in the negative impact of the air transportation and the provision with the necessary land resources for the airport infrastructure construction in case of the growth of the passenger traffic" is suitable for less influential and small airports (Lezhava, Kudryavtsev, 2010).
At the present time, attempts of the building-up regulation in the airport environs have exclusively restrictive nature. In Russia, lands around airports are considered by town planners mainly as zones of the negative impact of the large facility of the transport infrastructure on surrounding settlements. And, consequently, the regulations restricting building-up near the airport become a reflection of such phenomenon. At the same time, the positive impulse which the airport can give to surrounding territories often remains unrealized. As a result, there is no initiative and no idea of how similar territories shall develop in general taking into account all existing restrictions. Moreover, the majority of researches deal with the issues of technical, transport and economic nature and do not touch upon the interconnection of the airport and the city. As a rule, they are focused on the solution of specific tasks, but not comprehensive problems. Though some of them recognize the necessity to manage and control the airport from the environmental, economic and legislative point of view, they often do not attribute adequate significance to the regional planning (Cipriani, 2012).

\section{Conclusion}

One of the most effective tools of the development of the Pulkovo Airport environs is the formation of a separate planning zone on its basis with the development of the single development strategy. This strategy shall not only reflect the integrated development of the territory, but it also shall have the designated spatial structure. For this purpose, it is required to take into account those techniques and methods which were worked out in the international practice during the last 20 years, and consider possibilities of their transformation in local conditions. In the situation with Saint Petersburg we still have an opportunity to set a vector of development to the airport environs in view of the availability of the territorial resource for the development around the airport. The single strategy shall be effective for the city and the agglomeration as a whole, take into account interests of all interested parties (the airport operator, the Government of Saint Petersburg and the Leningrad Region, investors and developers) [11]. The development of a renewed concept of urban planning independent of the administrative belonging with longterm strategic tasks and effective management tools is needed. The principle of urban-planning exterritoriality of the airport environs, which shall receive their own status and united urban-planning documentation, shall be taken as the basis of such concept. Such situation is possible both at the level of the decision of two territorial entities of the Russian Federation and by means of the preparation of relevant changes in urban-planning documents, in particular, the Town Planning Code of the Russian Federation, as it previously happened with the notion of transport hubs. The introduction of the notion of the airport environs to the legal urban-planning practice will allow establishing conditions for their comprehensive and effective development more efficiently. 


\section{References}

Cipriani, L. (2012). Ecological airport urbanism. Airports and landscapes in the North East. Trento: Università degli Studi di Trento, p. 153.

Donnet, T., Keast, R.L. (2010). Cities in the airports 'shadow': underlying interests and discretionary power in airport-region development. In: Proceedings of the 12th WCTR World Conference on Transport Research, Lisbon.

Goncharova, O., Romanyuk, R. (2013). Iuzhnyi Peterburg - novaia investitcionnaia dolina [Southern Petersburg - a new investment valley]. "Ekspert Severo-Zapad": regional business magazine, 15, pp. 34-37. (in Russian)

Güller, M., Güller, M. (2001). From Airport to Airport City. Barcelona: Airports Region Conference.

Kasarda, J., Lindsay, G. (2012). Aerotropolis: The Way We'll Live Next. New York: Farrar, Straus and Giroux.

Klos, D. (2014). Airports as cities- the concept of aerotropolis applied to Helsinki-Vantaa International. Available at: http://www. theseus.fi/bitstream/handle/10024/77781/Klos_Dominika.pdf?sequence=1\&isAllowed=y (accessed on: 12.06.2017)

Laboratory of urban planning (2015). Analiticheskaia zapiska "Transportnye problemy Sankt-Peterburga, reshaemye na urovne kompleksnogo planirovaniia territorialnoi transportnoi sistemy" [Analytical note "Transport problems of St. Petersburg, solved at the level of integrated planning of the territorial transport system"]. Available at: http://labgrad.ru/d/180205/d/01_analiticheskayazapiska_problemytsspb29_05_2015.pdf (accessed on: 22.05.2017)

Legislative Services Agency (2012). Airport development zones. Available at: http://www.in.gov/legislative/pdf/IncomeTaxCreditReview2012.pdf (accessed on: 12.06.2017)

Lezhava, I.G., Kudryavtsev, F. S. (2010). Mezhdunarodnye aeroporty moskovskogo aviauzla kak resurs razvitiia moskovskoi aglomeratcii [International airports of the Moscow air hub as a resource for the development of the Moscow agglomeration]. Moscow: Moscow Architectural Institute (State Academy). (in Russian)

Marcos D.F.C., João de Abreu e Silva (2015). A review of airport concepts and their applicability to the new lisbon airport process. Revista Portuguesa de Estudos Regionais [Portuguese Journal of Regional Studies], 38, pp. 47-58.

Nefedov, V. (2017). Green infrastructure integration in the urban periphery. Proceedings of the Institution of Civil Engineers Urban Design and Planning, 170(2), pp. 47-58. DOI: 10.1680/jurdp.15.00047

Peneda, M.J.A., Reis, V.D., Maria do Rosário M.R. Macário (2011). Critical factors for the development of airport cities. Transportation Research Record: Journal of the Transportation Research Boar, 2214, pp. 1-9. DOI: 10.3141/2214-01

Schaafsma, M. (2010). From airport city to airport corridor. In: Proceedings of 1st International Colloqium on Airports and Spatial Development "Airports in Cities and Regions: Research and Practise", pp. 173-180.

Schlaack, J. (2010). Defining the Airea. In: Proceedings of 1st International Colloqium on Airports and Spatial Development "Airports in Cities and Regions: Research and Practise", pp. 113-125.

Thierstein, A.; Conventz, S. (2014). Hub Airports, the knowledge economy and how close is close? Evidence from Europe. In: Proceedings of 54th Congress of the European Regional Science Association "Regional development \& globalisation: Best practices". St. Petersburg, Russia.

Veretennikova, K. V. (2016). Printcipy klasternogo osvoeniia territorii vokrug aeroporta Pulkovo [Principles of the cluster development of the territory around the Pulkovo Airport]. Saint Petersburg. (in Russian) 